\title{
プラズマ対向機器用タングステン接合材料の機械的性質と微細組織に関する研究 Study on Mechanical Properties and Microstructures of Tungsten Joining Materials for Plasma Facing Components
}

\author{
OMOHD YUSAIRY BIN JAMIL ${ }^{1}$ (茨城大院) 車田 亮 $^{2}$ (茨城大工) 伊藤 吾朗 $^{2}$ (茨城大工) \\ 渡辺 英雄 ${ }^{3}$ (九大応力研) 松尾 明 $^{4}$ (日タン)
}

\begin{abstract}
1;MOHD YUSAIRY BIN JAMIL, Graduate School of Science and Engineering, Ibaraki University, 4-12-1, Nakanarusawa, Hitachi, Ibaraki, 316-8511.

2; Akira KURUMADA, Goro ITOH, College of Engineering, Ibaraki University.

3; Hideo WATANABE, Research Institute for Applied Mechanics, Kyushu University,

6-1, Kasugakouen, Kasuga, Fukuoka, 816-8580.

4; Akira MATSUO, Japan Tungsten Co, Ltd. 3173-2, Sonobe, Kiyama, Miyaki, Saga, 841-0203.
\end{abstract}

\begin{abstract}
Plasma facing materials for fusion experimental devices are required to have high thermal resistance, high thermal conductivity, thermal shock resistance, radiation damage resistance and so on. There are no materials of which properties are sufficient to meet the requirements. Because the plasma facing components are severely exposed to the high heat load and particles with high energy from fusion plasma, the high melting point metal such as a tungsten material is expected as a candidate material.

In this study, high energy ions are irradiated to the tungsten joining materials to apply them as an advanced structure material to the next fusion experimental devices. The relationship among the mechanical properties, the microstructures and the effects of radiation damage at the boundary parts of tungsten are made clear by an ultra micro hardness tester, SEM and TEM. And the thermal responses of the tungsten joining materials are also evaluated by electron beam heating tests.
\end{abstract}

Keywords: plasma facing materials, tungsten, mechanical properties, microstructure, radiation damage

\section{1. 序言}

核融合炉用プラズマ対向材料は、高熱負荷、高粒子負荷、 中性子による照射損傷などを受けるため、耐熱性、高熱伝導 性、耐熱衝撃性、耐照射損傷性などに優れていなければなら ない。現在、それら特性を十分に满足する材料は皆無に等し い。このような中で、タングステン等の高融点金属材料の使 用が検討されている。

本研究では、タングステン接合材料及びその母材の機械的 特性に及ぼす照射損傷の影響を究明するために、中性子照射 を模擬したイオン照射試験を行い、その照射前後で、超微小 硬さ試験と微細組織の観察を行った。さらに、電子ビーム加 熱試験を行い、熱応答特性の評価も行った。

\section{2. 実跧方法}

本研究では、日本タングステン侏社製の純度 $99.95[\%] の$ 微

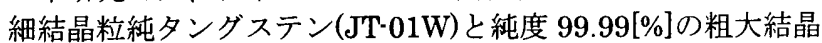
粒純タングステン(JT-02W)を中心に、市販の純度 $99.5 \%$ の純 タングステンも加えて実験に用いた。

Fig.1(a)と Fig.1 (b)は、JT-01W と JT-02W の組織写真を示 す。JT-01W と JT-02W の結晶粒径は、それぞれ、約 $10[\mu \mathrm{m}]$ 及び $710[\mu \mathrm{m}]$ である。これらのタングステンは、市販のタン グステンとは異なり、層状の結晶組織を示さず、ほぼ球状の 等方的な組織を示している。

JT-01W および JT-02W と無酸素銅との接合には、応力緩和 のためモリブデンを中間材として用いた治金接合法と、直接 接合する NDB(Non Defective Bonding)接合法を用いた。

これらの接合材料に、九州大学応用力学研究所の高エネル ギーイオン発生装置を用いて、 $2.4 \mathrm{MeV}$ の銅イオン $\left(\mathrm{Cu}^{2+}\right)$ を照 射した。その場合の銅部分及びタングステン部分の照射損傷

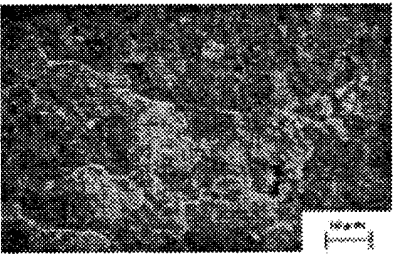

(a) JT-01W

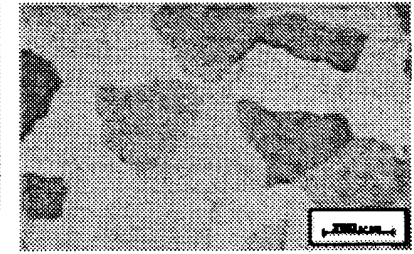

(b) JT02W
Fig.1 Microstructures of tungsten materials

量は、それぞれ、銅部分では,5.5[dpa]、55[dpa]照射となり、 タングステン部分では 3.6[dpa]、36[dpa]照射となった。

機械的特性は、超微小硬さ試験により評価した。試験荷重 は照射イオンの飛程付近の特性変化を求めるため、 $19.6 \mathrm{~m} \mathrm{~N}$ とした。この試験によるダイナミック硬さは次式で算出され る。

$$
D_{h} \equiv \alpha L / h^{2}
$$

ここで、 $L[\mathrm{mN}]$ は試験荷重、 $h[\mu \mathrm{m}]$ は圧子の試料への侵入 量（押し込み深さ）、 $\alpha$ は圧子形状による定数で、三角錐圧子 の場合 $\alpha=3.8584$ となる。硬さの試験結果は、照射領域を中 心部とその外周部に分けて、0-1、1-2、2-3、3-4mm の 領域内で詳細に検討した。それぞれの部分で 5〜10 回の測定 を行い、その平均值で評価した。また、電子ビーム加熱装置 を用いて、接合界面の熱応答特性の比較評価を行った。

\section{3. 実跧結果及び考察}

Fig.2 は、中間材に Mo を挿入した JT-01W 及び JT-02W の 接合材について、ダイナミック硬さの未照射との増加率を示 す。Fig.2(a)より、JT-01W タングステン部分 $(0.0 \sim 1.0 \mathrm{~mm})$ 


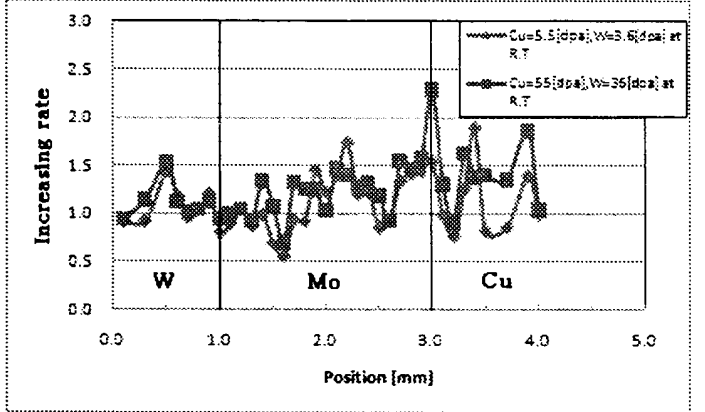

(a) $\mathrm{JT}-01 \mathrm{~W}-\mathrm{Mo}-\mathrm{Cu}$

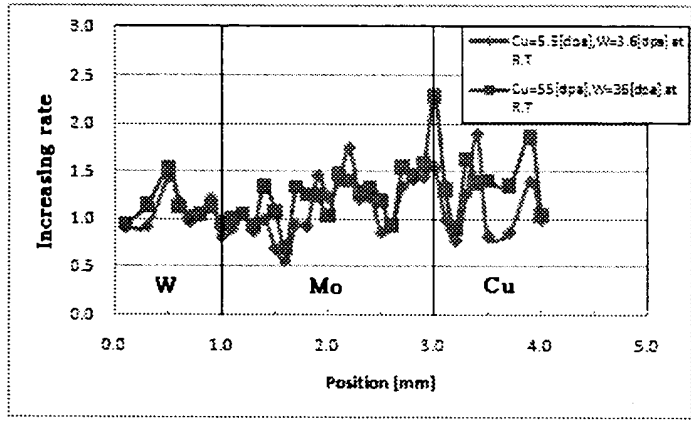

(b) $\mathrm{JT}-02 \mathrm{~W}-\mathrm{Mo}-\mathrm{Cu}$

Fig.2 Increasing rate of dynamic hardness at W-Mo-Cu joining parts due to $\mathrm{Cu}^{2+}$ ion irradiation.

においては、未照射との増加率をその領域内で平均した場合、 3.6 [dpa]照射で約 6 [\%]のダイナミック硬さの増加、36[dpa]照

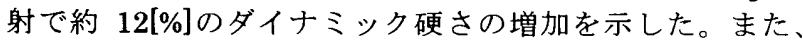
Fig.2(b)より、JT-02W タングステン部分 $(0.0 \sim 1.0 \mathrm{~mm})$ にお いては、未照射との増加率をその領域内で平均した場合、 3.6 [dpa]照射で約 3[\%]のダイナミック硬さの増加、36[dpa]照

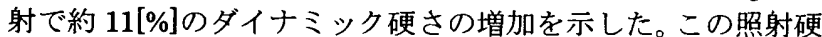
化は、照射欠陥の増大及び転位の移動阻害などが原因であり、 照射量の増大に伴って増大した。

Fig.3 は、JT-01W と JT-02W を用いた NDB 接合材につい て、未照射との増加率を示す。前述と同様に、接合界面近傍 の $1 \mathrm{~mm}$ の領域内で、未照射との増加率を平均した場合、 $\mathrm{JT}-01 \mathrm{~W}$ タングステン部分 $(1.0 \sim 2.0 \mathrm{~mm})$ においては、室温で の 3.6[dpa]照射では 5\%の増加、36[dpa]照射では $20 \%$ の増加、 $573 \mathrm{~K}$ での 36 [dpa]照射では $22 \%$ の增加を示した。また、 JT-02W タングステン部分（1.0 2.0mm）においては、室温で の 3.6 [dpa]照射では $18 \%$ の増加、 $573 \mathrm{~K}$ での 3.6 [dpa]照射で は $20 \%$ の増加を示した。 $573 \mathrm{~K}$ の高温照射においても、室温 照射とほぼ等しい照射硬化を示した。

Fig. 2 と Fig. 3 より、タングステンの照射硬化は、モリブデ ンや銅よりも小さく、タングステンが耐照射損傷性を有して いた。また、NDB 接合法による接合界面付近の硬さは、Mo を挿入した場合よりも硬さの増加率が大きいことがわかった。 一方、中間材に Mo を挿入した JT-01W および JT-02W の接 合試験体の熱負荷試験の結果は、 $12\left[\mathrm{MW} / \mathrm{m}^{2}\right]$ の高熱負荷時で は、JT-01W が純タングステンの表面温度より若干低い值を示 し、その表面温度が約 $1400 \mathrm{~K}$ になった。また、NDB 接合法 で接合した JT-01W と JT-02W の接合試験体の熱負荷試験の 温度を外挿してみると、 $12\left[\mathrm{MW} / \mathrm{m}^{2}\right]$ の熱負荷に対して、

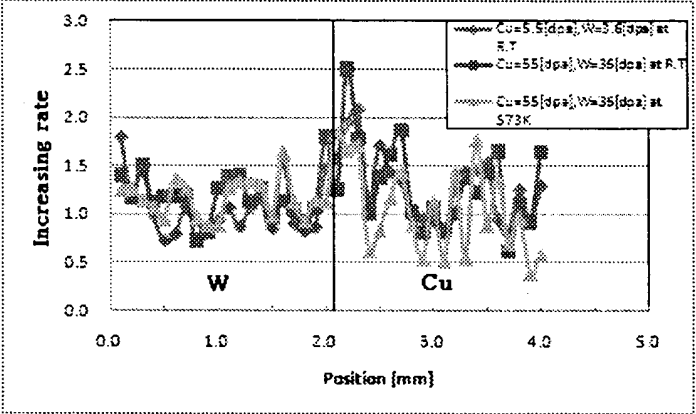

(a) $\mathrm{JT}-01 \mathrm{~W}-\mathrm{Cu}$

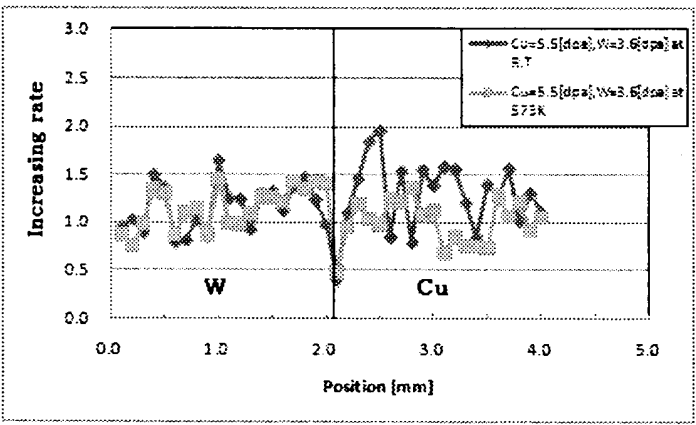

(b) JT-02W-Cu

Fig.3 Increasing rate of dynamic hardness at W-Cu joining parts by $\mathrm{NDB}$ due to $\mathrm{Cu}^{2+}$ ion irradiation.

JT-01W の場合で約 $1100[\mathrm{~K}] 、 J T-02 \mathrm{~W}$ の場合で約 $1200[\mathrm{~K}]$ と 予想され、タングステンの再結晶温度以下であった。以上の 結果、NDB 法によるタングステンプラズマ対向機器は、良好 な熱応答特性を示し、次期核融合実験装置への応用が期待で きた。

\section{4. 結言}

本研究は、タングステン材料を核融合炬用プラズマ対向機 器へ応用するために、イオン照射試験を行い、タングステン 接合材料の機械的特性に及ぼすイオン照射効果を究明した。 また、電子ビーム加熱試験による接合試験体の熱応答特性の 評価も行った。以下に得られた結果を示す。

（1） $\mathrm{Cu}^{2+}$ イオン照射試験を行った結果、照射欠陥の増大、転 位の移動阻害などにより、照射量の増大に伴うダイナミ ック硬さの増加を示した。また、タングステンの照射硬 化は、モリブデンや銅よりも小さく、タングステンが耐 照射損傷性を有していることが分かった。

（2）JT- $01 \mathrm{~W}$ および JT- $02 \mathrm{~W}$ と無酸素銅との直接的に NDB 接合した接合試験体は、12[MW/m $\left.{ }^{2}\right]$ の熱負荷に対して、 その表面温度が約 1100 1200[K]で、タングステンの再 結晶温度以下であった。従って、NDB 法によるタング ステンプラズマ対向機器は、良好な熱応答特性を示し、 次期核融合実験装置への応用が期待できた。

\section{参考文献}

（1）小林,本橋,他,日本機械学会講演論文集, Vol.37，(2002), pp.104-105.

（2）田辺,丸山,他,プラズマ・核融合学会誌,Vol.69,No.5,(1993), pp. 441-444. 